\title{
Examining the absorptive capacity construct: A validation study in the Pakistani banking context
}

\author{
Waheed Ali Umrania* $^{{ }^{*}, \text { Umair Ahmed }^{\mathrm{b}} \text { and Pervaiz Ahmed Memon }}{ }^{\mathrm{a}}$
}

${ }^{a}$ Sukkur Institute of Business Administration, Sindh, Pakistan ${ }^{b}$ University Utara Malaysia, Malaysia

\begin{tabular}{l}
\hline C H R O N I C L E \\
\hline Article history: \\
Received March 5, 2015 \\
Received in revised format \\
August 162015 \\
Accepted October 272015 \\
Available online \\
October 282015 \\
\hline Keywords: \\
Absorptive capacity \\
ACAP \\
Construct validity \\
Banks \\
Pakistan
\end{tabular}
\begin{abstract}
A B S T R A C T
The psychometric properties of the Absorptive capacity construct have been assessed in this study in the context of Pakistan. A total of 201 bank managers were included in the survey. Data analysis using the Smart PLC 3.0 revealed that the scale has satisfactory level of internal consistency reliability, conversion validity and discriminant validity. The findings refer to the fact that the ACAP construct could be responsively used in measuring the absorptive capacity in the banking sector of Pakistan.
\end{abstract}

\section{Introduction}

Absorptive capacity [ACAP] over the years has received mementos popularity. Absorptive capacity is defined as an organization`s pre-existing capability to be inclined towards seeking information from external sources for opportunity identification. (Hamel \& Prahalad, 1994; Van den Bosch et al., 1999). Studies have underscored that ACAP has the potential to influence numerous organizational variables such as business performance, intro-organizational learning, intra-organizational transfer of knowledge, organizational innovation and competitive advantage (Gupta \& Govindarajan, 2000; Lane et al., 2001; Tsai, 2001; Zahra \& George, 2002). ACAP also helps in improving existing company procedures and practices through bringing innovation and help to transform knowledge paradigms within an organization (del Carmen Haro-Dominguez et al., 2007). The significance of measuring and evaluating absorptive capacity is critical for business to outline as to what extent the organization is willing and capable of assimilating, acquiring, exploiting and transforming the knowledge from external sources for the achievement of company objectives. ACAP scale is a well-established tool * Corresponding author.

E-mail address: waheed.ali@iba-suk.edu.pk (W. A. Umrani) 
used to measure the absorptive capacity of a firm and this paper aims to further the area of knowledge through validating it in the Pakistan`s context.

\section{Literature review}

Cohen and Levinthal (1989) published their work on ACAP, conceptualizing it as, an organization`s potential and capability for identifying, assimilating and exploiting knowledge acquired from external sources. According to Cohen and levinthal (1989), these three dimensions of absorptive capacity are critical for an organization to outline, specify and evaluate the knowledge acquisition from external sources for subsequent usage.

Zahra and George (2002) further investigated the concept forwarded by Cohen and Levinthal (1989) and enhanced ACAP dimensions as acquisition, assimilation, transformation and exploitation. Acquisition denotes to an organization's ability for identifying and obtaining relevant information from outside company sources. The term assimilation refers to the establishment of routines and processes that play a critical role in the examination, interpretation and comprehension of information obtained from outside sources (Szulanski, 1996). However, development and refinement of the assimilated routines in order to assist the combination of existing and obtained knowledge is referred as transformation (Zahra \& George, 2002).

Exploitation is explained as the capacity of a firm for improving, expanding and using the prevailing technology, routines and capableness to unfold new entities from the transformed knowledge (del Carmen Haro-Dominguez et al., 2007).

According to Cohen and Levinthal (1989), the absorptive capacity was initially measured using nominal R\&D proxies and majority of the research has outlined a dire need for developing a comprehensive tool for measuring on this, Flatten et al. (2011), developed and empirically validated a more comprehensive scale of ACAP. Based on comprehensive literature review, a 52 item questionnaire was developed initially for pre-testing of ACAP scale. A total of 3 pre-tests were conducted involving company executives and academic experts. The pre-tests helped to eliminate ambiguous and difficult questions, lowering the number from 52 to 36 . Company membership data from German Chamber of Commerce was used to generate two samples consisting of CEOs, senior executives and employees from chemical, mechanical and electrical engineering industries. The samples consisted of 285 and 361 were taken to participate in the study through web-based survey. The results of the study yielded that the ACAP scale consists of four dimensions with 14 valid items.

Based on the suggestions of Flatten et al. (2011) for further validation of ACAP scale in other countries and industries, this study has attempted to validate ACAP scale in the banking industry of Pakistan. In doing so, the study has addressed the following question:

What are the psychometric properties of ACAP and its factor structure in the context of banking sector of Pakistan?

\section{The proposed study}

\subsection{Objectives}

Developed in Germany, the use of ACAP scale is increasing in developed countries. But unfortunately, there have been no studies examining the robustness of the Absorptive capacity scale in the Pakistani context. This underlines a potential research and knowledge gap. The present study therefore occupies to focus on a single primary objective which is to validate the psychometric properties of ACAP and its factor structure in the context of the banking sector of Pakistan. 


\subsection{Rational of the study}

ACAP is an increasingly popular and sought tool for measuring absorptive capacity of a firm. Absorptive capacity inhabit a strategic nature in influencing organizational performance (Lichtenthaler, 2009).

This study upholds several significant features, first being the scale validation. To the best of our knowledge, this paper is the first to validate the ACAP scale in the developing economy, particularly in Pakistan. Furthermore, the results of the study lay encouraging ground for its use in future studies on absorptive capacity.

\subsection{Methods}

A total of 1385 branches of the big five banks in four largest cities of Pakistan are listed by the Pakistan Banks Association, (2014). Based on the recommendation of Krejcie and Morgan (1970), a total of 500 survey forms were posted using the stratified random sampling with stamped return envelopes. Out of the total 236 returned survey forms, only 201 were found appropriately filled.

In this survey, a total of 88.1 percent from the 201 participants were male, leaving 11.9 percent as female. In connection to age, 28.9 percent belonged below 30 years age group whereas 45.8 percent related to 30-40 years and 20.4 percent related to $41-52$ year category. Only 5 percent related to the age group of 51-60 years. On the ground of qualification, 70.1 percent mentioned holding a postgraduate degree whereas 26.9 percent outlined having an undergraduate and only 1.5 percent underlined having an associate degree in banking.

With reference to work experience, 45.8 percent mentioned having less than 3 years of work experience; 30.3 percent belonging to 3-6 years category; 16.4 percent to 7-10 years category and 3 percent to $11-13$ years category. The remaining 4.5 percent outlined having more than 13 years of work experience.

Absorptive capacity (ACAP) construct (Flatten et al., 2011) was examined in the Pakistani context. The construct comprised of four dimensions was measured through five point Likert scale

Confirmatory factor analysis (CFA) was implied using Smart PLS 3 (Ringle et al., 2015) for the objective of construct validation of ACAP in the Pakistani context. In order to ascertain internal consistency reliability, convergent validity and discriminant validity, the PLS algorithm (Geladi \& Kowalski, 1986) was performed (Henseler et al., 2009). The results of the confirmatory factor analysis for ACAP are provided in Table 1.

Two items relating to Assimilation (ACKAS1 and ACKAS5) and one item concerning to Exploitation (ACKE3) were deleted due to lower loadings. The Table 1 draws that ACAP has four dimensions as a result of CFA. The composite reliability coefficient was used to determine the internal consistency reliability following the recommendations of Hair et al. (2011). According to them, the minimum cut off for composite reliability coefficient is 0.70 or greater. Table 1 indicates that the composite reliability coefficients of the present study have ranged between 0.879 and 0.889 which thereby exceeds the minimum threshold (Hair et al., 2011). This therefore demonstrates that the present study results have satisfactory level of internal consistency reliability.

Following the recommendation of Fornell and Larcker (1981), we next examined the convergent validity by evaluating Average Variance Extracted (AVE) of every individual latent construct. Chin (1998) suggests 0.5 or above cut off for AVE of each latent construct. Table 1 shows that AVE values for each of the latent construct are higher compared to the recommended threshold of 0.5. Therefore, all four dimensions of ACAP have achieved the convergent validity criteria. Thus all the dimensions of CEAI met the criterion of convergent validity. 
Table 1

Results of confirmatory factor analysis for ACAP

\begin{tabular}{|c|c|c|c|c|c|}
\hline \multirow[t]{2}{*}{ Code } & \multirow[t]{2}{*}{ Indicator } & \multicolumn{4}{|c|}{ Component/Loadings } \\
\hline & & Acquisition & Assimilation & Exploitation & Transformation \\
\hline ACKA1 & $\begin{array}{l}\text { The search for relevant information } \\
\text { concerning our industry is every-day } \\
\text { business in our company. }\end{array}$ & 0.828 & & & \\
\hline ACKA2 & $\begin{array}{l}\text { Our management motivates the employees } \\
\text { to use information sources within our } \\
\text { industry. }\end{array}$ & 0.877 & & & \\
\hline ACKA3 & $\begin{array}{l}\text { Our management expects that the } \\
\text { employees deal with information beyond } \\
\text { our industry. }\end{array}$ & 0.851 & & & \\
\hline ACKAS2 & $\begin{array}{l}\text { Our management emphasizes cross- } \\
\text { departmental support to solve problems. }\end{array}$ & & 0.897 & & \\
\hline ACKAS4 & $\begin{array}{l}\text { In our company there is a quick information } \\
\text { flow, e.g., if a business unit obtains } \\
\text { important information it communicates this } \\
\text { information promptly to all other business } \\
\text { units or departments. }\end{array}$ & & 0.874 & & \\
\hline ACKE1 & $\begin{array}{l}\text { Our company regularly reconsiders } \\
\text { technologies and adapts them accordant to } \\
\text { new knowledge. }\end{array}$ & & & 0.907 & \\
\hline ACKE2 & $\begin{array}{l}\text { Our company has the ability to work more } \\
\text { effective by adopting new technologies. }\end{array}$ & & & 0.882 & \\
\hline ACKT1 & $\begin{array}{l}\text { Our employees have the ability to structure } \\
\text { and to use collected knowledge. }\end{array}$ & & & & 0.827 \\
\hline ACKT2 & $\begin{array}{l}\text { Our employees are used to absorb new } \\
\text { knowledge as well as to prepare it for } \\
\text { further purposes and to make it available. }\end{array}$ & & & & 0.745 \\
\hline ACKT3 & $\begin{array}{l}\text { Our employees successfully link existing } \\
\text { knowledge with new insights. }\end{array}$ & & & & 0.842 \\
\hline ACKT4 & $\begin{array}{l}\text { Our employees are able to apply new } \\
\text { knowledge in their practical work. }\end{array}$ & & & & 0.819 \\
\hline Average $\mathrm{V}$ & riance Extracted (AVE) & 0.726 & 0.785 & 0.800 & 0.655 \\
\hline Composite & Reliability (CR) & 0.888 & 0.879 & 0.889 & 0.883 \\
\hline
\end{tabular}

NOTE: ACKA refers to Acquisition; ACKAS to Assimilation; ACKE to Exploitation and ACKT referring to Transformation.

Table 2

Discriminant validity of the construct

\begin{tabular}{lllll}
\hline & 1 & 2 & 3 & 4 \\
\hline Acquisition & $\mathbf{0 . 8 5 2}$ & & & \\
Assimilation & 0.603 & $\mathbf{0 . 8 8 6}$ & & \\
Exploitation & 0.448 & 0.430 & $\mathbf{0 . 8 9 5}$ & $\mathbf{0 . 8 0 9}$ \\
\hline Transformation & 0.420 & 0.476 & 0.620 & \\
\hline
\end{tabular}

Note: The correlations of the latent constructs and AVE (values in bold face)

According to Fornell and Larcker (1981) when the square root of AVE exceeds than the correlation among the latent constructs, it confirms the presence of discriminant validity. Table 2 underscores that the constructs fulfill the discriminant validity criterion depicting sufficient psychometric properties for ACAP dimensions (Fornell \& Larcker, 1981).

\section{Discussion and conclusion}

ACAP scale has been highly regarded and acknowledged for its contribution towards understanding an organization`s knowledge sharing, learning and capability building behaviors (Lane et al., 2006; Zahra \& George, 2002). The four dimensions of ACAP scale facilitates to outline the overall potential and intent of a firm towards the knowledge acquisition activities, assimilation of the acquired information 
into usable knowledge, transformation of the adopted knowledge and considerable exploitation of the transformed knowledge to achieve competitive edge.

This study strived to validate the ACAP scale (Flatten et al., 2011) in the Pakistani context, more precisely in the banking sector of Pakistan. The CFA findings have concluded that ACAP is a multidimensional construct, comprising of four dimensions namely Acquisition, Assimilation, Exploitation and Transformation. The findings are parallel to the previous studies (Flatten et al., 2011) that validated the ACAP dimensions. The CFA, reliability and validity tests have confirmed the four dimensions of ACAP are evidently appropriate to measure absorptive capacity in the banking sector of Pakistan as well.

The study forwards and recommends ACAP as a rigorous scale for the top management in assessing the strengths and weaknesses of their respective organizations within the Pakistani context. The scale can also be used to potentially compare a firm`s ACAP against their counter parts.

\section{References}

Chin, W. W. (1998). The partial least squares approach to structural equation modeling. Modern Methods for Business Research, 295(2), 295-336.

Cohen, W. M., \& Levinthal, D. A. (1989). Innovation and learning: the two faces of R \& D. The Economic Journal, 99(897), 569-596.

del Carmen Haro-Domínguez, M., Arias-Aranda, D., Lloréns-Montes, F. J., \& Moreno, A. R. (2007). The impact of absorptive capacity on technological acquisitions engineering consulting companies. Technovation, 27(8), 417-425.

Flatten, T. C., Engelen, A., Zahra, S. A., \& Brettel, M. (2011). A measure of absorptive capacity: Scale development and validation. European Management Journal, 29(2), 98-116.

Fornell, C., \& Larcker, D. F. (1981). Evaluating Structural Equation Models with unobservable variables and measurement error. Journal of Marketing Research 18(1), 39-50.

Geladi, P., \& Kowalski, B. (1986). Partial least-squares regression: A tutorial. Analytica Chimica Acta, 185, 1-17.

Gupta, A. K., \& Govindarajan, V. (2000). Knowledge flows within multinational corporations. Strategic management journal, 21(4), 473-496.

Hair, J. F., Ringle, C. M., \& Sarstedt, M. (2011). PLS-SEM: Indeed a Silver Bullet. Journal of Marketing Theory and Practice, 18(2), 139-152.

Hamel, G., \& Prahalad, C. K. (1994). Competing for the futureHarvard Business School press. Boston, MA.

Henseler, J., Ringle, C. M., \& Sinkovics, R. R. (2009). The Use of Partial Least Squares Path Modeling in International Marketing. In R. R. Sinkovics \& P. N. Ghauri (Eds.), Advances in International Marketing (Vol. 20, pp. 277-320). Bingley: Emerald

Lane, P. J., Koka, B. R., \& Pathak, S. (2006). The reification of absorptive capacity: A critical review and rejuvenation of the construct. Academy of management review, 31(4), 833-863.

Lane, P. J., Koka, B. R., \& Pathak, S. (2006). The reification of absorptive capacity: A critical review and rejuvenation of the construct. Academy of management review, 31(4), 833-863.

Lane, P. J., Salk, J. E., \& Lyles, M. A. (2001). Absorptive capacity, learning, and performance in international joint ventures. Strategic management journal, 22(12), 1139-1161.

Lichtenthaler, U. (2009). Absorptive capacity, environmental turbulence, and the complementarity of organizational learning processes. Academy of Management Journal, 52(4), 822-846.

Ringle, C. M., Wende, S., and Becker, J.-M. (2015). SmartPLS 3. Boenningstedt: SmartPLS GmbH, http://www.smartpls.com.

Szulanski, G. (1996). Exploring internal stickiness: Impediments to the transfer of best practice within the firm. Strategic management journal, 17(S2), 27-43. 
Tsai, W. (2001). Knowledge transfer in intraorganizational networks: Effects of network position and absorptive capacity on business unit innovation and performance. Academy of management journal, 44(5), 996-1004.

Van Den Bosch, F. A., Volberda, H. W., \& De Boer, M. (1999). Coevolution of firm absorptive capacity and knowledge environment: Organizational forms and combinative capabilities. Organization science, 10(5), 551-568.

Wang, C. L., \& Ahmed, P. K. (2007). Dynamic capabilities: A review and research agenda. International journal of management reviews, 9(1), 31-51.

Zahra, S. A., \& George, G. (2002). Absorptive capacity: A review, reconceptualization, and extension. Academy of management review, 27(2), 185-203.

Zahra, S. A., \& George, G. (2002). Absorptive capacity: A review, reconceptualization, and extension. Academy of management review, 27(2), 185-203. 